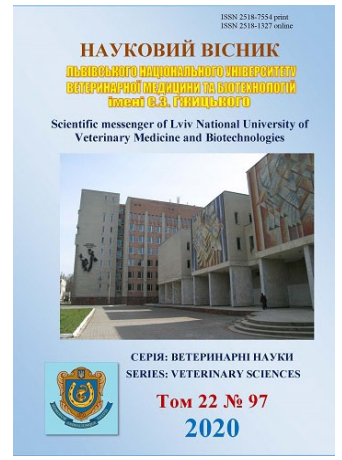

\author{
Науковий вісник Дьвівського націонадьного університету \\ ветеринарної медицини та біотехнологій імені С.3. Гжицького. \\ Серія: Ветеринарні науки \\ Scientific Messenger of Lviv National University \\ of Veterinary Medicine and Biotechnologies. \\ Series: Veterinary sciences
}

\title{
Morphological particulars of the liver of laying hens of cross "Lohmann Brown" under hepatosis
}

\author{
V. Y. Yaremchuk, L. G. Slivinska, Y. S. Stronskyi \\ Stepan Gzhytskyi National University of Veterinary Medicine and Biotechnologies Lviv, Ukraine
}

Article info

Received 29.01.2020

Received in revised form 28.02.2020

Accepted 29.02.2020

Stepan Gzhytskyi National University of Veterinary Medicine and Biotechnologies Lviv, Pekarska Str., 50, Lviv, 79010, Ukraine.

Tel.: +38-063-649-99-20 E-mail:vasulunkadunets@ukr.net
Yaremchuk, V. Y., Slivinska, L. G., \& Stronskyi, Y. S. (2020). Morphological particulars of the liver of laying hens of cross "Lohmann brown" under hepatosis. Scientific Messenger of Lviv National University of Veterinary Medicine and Biotechnologies. Series: Veterinary sciences, 22(97), 69-73. doi: $10.32718 /$ nvlvet9712

The article presents the results of histological examinations of the liver of laying hens at age 166, 300 and 530 days, in which according to the results of biochemical analysis of blood serum revealed a subclinical course of hepatosis. The purpose of our study was the early diagnosis of this pathology and the study of the histological structure of the liver in different periods of poultry productivity. The work was performed at LLC Agro Firm "Zagai" of Kamianka-Buzkyi district of Lviv region. Autopsy and examination of histological specimens were performed at the Department of Normal and Pathological Morphology and Forensic Veterinary at Stepan Gzhytskyi National University of Veterinary Medicine and Biotechnologies Lviv. The macroscopic examination of the liver showed that in part of laying hens at 166 days of age, in most of laying hens at 300 days old and in all of laying hens at 530 days old examined, the liver was slightly enlarged, of a sluggish consistency and unevenly colored. It should also be noted that, in addition to severe dystrophic changes in the liver, 530 days of laying hens also showed signs of general obesity. The study of histological specimens installed that in part of laying hens at 166 days of age, the liver lobules were disordered, in resulting was disrupted their beam structure. At the same time, cytoplasm of hepatocytes is somewhat cloudy and visible granularity. In laying hens at age 300 and 530 days installed the discomplexation of the beam structure of the organ and the presence of small and large droplets of fat vacuoles in hepatocytes are indicated, which indicate about the development of fatty dystrophy. The results of the morphological study indicate the presence in the liver of laying hens signs of acute and chronic pathological processes, which with age are complicated by dystrophic changes of the organ.

Key words: laying hens, age dynamics, liver, hepatocytes, histostructure, hepatosis, obesity.

\section{Морфологічні особливості печінки курей-несучок кросу “Ломан Браун” за гепатозу}

В. Ю. Яремчук, Л. Г. Слівінська, Ю. С. Стронський

Львівський наиіональний університет ветеринарної медицини та біотехнологій імені С. 3. Гжиџького, м. Львів, Україна

У статті наведені результати гістологічних досліджень печінки курей-несучок віком 166, 300 та 530 діб, у яких прижиттєво за результатами біохімічного аналізу сироватки крові було встановлено субклінічний перебіг гепатозу. Метою нашого дослідження була рання діагностика даної патологї та вивчення гістологічної будови печінки в різні періоди продуктивності птиці. Робота виконували в ТОВ Агрофірмі “Загаї” Кам'янка-Бузького району Львівської області. Розтин трупів та дослідження гістологічних зрізів проводили на кафедрі нормальної та патологічної морфологї і судової ветеринарї Львівського національного університету ветеринарної медицини та біотехнологій імені С. З. Гжицького. За макроскопічного дослідження печінки встановлено, ияо у частини курей віком 166 діб, більшості 300 та у всіх досліджуваних курей віком 530 діб печінка була дещо збільшена, в ялої консистениї та нерівномірно забарвлена. Варто також зазначити, шео у курей-несучок віком 530 діб, окрім виражених дистрофічних змін у 
печінці, також виявляли ознаки загального ожиріння. Дослідженням гістологічних препаратів встановлено, щцо у частини курейнесучок віком 166 діб печінкові часточки розташовувались невпорядковано, внаслідок чого була порушена їхня балкова будова. При иьому иитоплазма гепатоцитів дещчо мутнувата і проглядається зернистість. У курей-несучок віком 300 та 530 діб встановлено дискомплексацію балкової структури органа та наявність дрібнокрапельних і крупнокрапельних жирових вакуолей у гепатоцитах, щзо вказує на розвиток жирової дистрофії. Результати морфологічного дослідження свідчать про наявність в печінці курейнесучок ознак гострих та хронічних патологічних прочесів, які з віком ускладнюються дистрофічними змінами органа.

Ключові слова: кури-несучки, вікова динаміка, печінка, гепатоцити, гістоструктура, гепатоз, ожиріння.

Вступ

Сучасна технологія утримання високопродуктивних кросів курей-несучок підвищує ризик виникнення у птиці метаболічних розладів, оскільки в особливо напруженому режимі функціонують печінка, нирки, органи ендокринної системи, яєчники, а також фосфорно-кальцієвий i D-вітамінний обміни (Melnyk, 2015; El-Katcha et al., 2019). Найбільше навантаження на себе бере печінка - центральний орган дезінтоксикації, нейтралізації токсинів і їх підготовки до виведення $з$ організму. Вона бере пряму чи опосередковану участь в усіх обмінних процесах, а функціональні зміни гепатоцитів спричиняють порушення як у системах органів, так і в організмі загалом (Nikitin et al., 1985; Dunets \& Slivinska, 2017).

Вивчення гістологічної будови печінки дає можливість визначити структурно-функціональний стан органа. Однак відомості про морфологію печінки у птиці нечисленні, мають відмінності та іноді суперечливі (Vrakin \& Sidorova, 1999). Недостатньо розкрито морфогенез печінки курей-несучок в найкритичніші етапи та фази постнатального онтогенезу. У літературі нами не виявлено даних про вікову морфологію печінки у курей-несучок кросу “Ломан Браун” з урахуванням розвитку органа на різних етапах розвитку і фазах продуктивності. Результати досліджень мають не тільки теоретичний і науковий інтерес, а й важливе значення в практичній ветеринарній медицині галузі птахівництва (Erehina, 1990; Bodrova, 2009).

Аналізуючи дослідження останніх років, зауважимо, що згідно $з$ даними розтинів трупів птиці патології печінки реєструють майже у кожної курки-несучки (Horalskyi et al., 2005; Hohlov, 2007; Kelberg \& Sadovnikov, 2010; Vashchyk et al., 2020), а саме: часто діагностують гепатоз птиці.

Метою нашої роботи було дослідження гістологічної будови печінки курей-несучок кросу “Ломан Браун” в різних періодах розвитку та продуктивності 3 метою ранньої діагностики, лікування та профілактики гепатозу.

\section{Матеріал і методи досліджень}

Дослідження виконували в ТОВ Агрофірмі “Загаї” Кам'янка-Бузького району Львівської області й на кафедрі внутрішніх хвороб тварин та клінічної діагностики Львівського національного університету ветеринарної медицини та біотехнологій імені С. 3. Гжицького. Об'єктом дослідження були кури яєчного напрямку продуктивності кросу “Ломан Браун” віком 166, 300 і 530 діб. Патологоанатомічне дослідження проводилось на 10 курях-несучках із кожної вікової категорії. Всі групи курей утримувались за однакових параметрів мікроклімату приміщення (температура повітря - $16-18{ }^{\circ} \mathrm{C}$, відносна вологість 60-70\%). Годівлю здійснювали повноцінним комбікормом, передбаченим технологічною картою для даного віку та кросу птиці.

Розтин трупів птиці проводили в прозекторії кафедри нормальної та патологічної морфології і судової ветеринарії методом часткового розчленування (Bancroft et al., 2013). Зразки печінки для досліджень відбирали з однієї ділянки правої частки органа, фіксували в $10 \%$ водному розчині нейтрального формаліну, зневоднювали у спиртах зростаючої концентрації 3 подальшою заливкою у парафін. Гістологічні зрізи товщиною 4-5 мкм виготовляли із парафінових блоків на санному мікротомі МС-2. Фарбували гістозрізи гематоксиліном та еозином за загальноприйнятою методикою (Sarkisova \& Perova, 1996). Готові препарати розглядали під світловим мікроскопом Leica DM-2500 (Switzerland), фотографували їх фотокамерою Leica DFC450C з програмним забезпеченням Leica Application Suite Version 4.4.

При виконанні експериментальних досліджень на курях-несучках дотримано всіх біоетичних норм стосовно тварин, що відповідають вимогам Закону України № 3447-4 "Про захист тварин від жорстокого поводження”, положенню Свропейської конвенції щодо захисту хребетних тварин, яких використовують в експериментальних та інших наукових цілях (Страсбург, 1986) та положенню про використання хребетних тварин для дослідних та інших наукових цілей у Львівському національному університеті ветеринарної медицини та біотехнологій імені С. 3. Гжицького.

\section{Результати та їх обговорення}

При клінічному обстеженні курей-несучок у 83 \% встановлено середню вгодованість. Температура тіла, частота пульсу і дихання були в межах норми. Куринесучки віком 300 і 530 діб були малорухливі, більше сиділи та неактивно реагували на зовнішні подразники. Варто зазначити, що досліджувані кури-несучки віком 530 діб були з вираженими округлими формами тіла (Dunets \& Slivinska, 2018).

Попередніми нашими дослідженнями (Dunets \& Slivinska, 2018) біохімічного аналізу крові встановлено гіперпротеїнемію у $53,3 \%$ i $66,7 \%$ курей-несучок віком 300 і 530 діб відповідно. Виявлено підвищення активності гепатоспецифічних ензимів АлАТ та АсАТ у 53,3\% і $100 \%$ курейнесучок віком 166 діб, у 66,7\% і $100 \%$ - 300 діб, у $80 \%$ і $100 \%$ - 530 діб відповідно. 3 віком встановлена тенденція збільшення кількості курей- 
несучок зі зниженням концентрації сечовини в крові (166 діб - 13,3 \%; 300 діб - 23,3\%; 530 діб - 36,7\%). Гіперурикемія виявлена у $26,7 \%, 16,7 \%$ та $10 \%$ курей-несучок віком 166, 300 і 530 діб відповідно. Збільшення рівня загального холестеролу діагностували у 26,7 \% курей-несучок віком 166 діб, у 43,3\% - 300 діб та у 63,3\% - 530 діб. Результати біохімічного аналізу сироватки крові свідчать про субклінічний перебіг гепатозу (Dunets \& Slivinska, 2018).

Для підтвердження діагнозу було проведено контрольний забій, патолого-анатомічний розтин та гістологічне дослідження печінки курей-несучок віком 166, 300 і 530 діб. Варто зазначити, що основні зміни були виявлені в печінці, однак дані літератури свідчать про наявність патологічних змін в нирках та серці (Danilov \& Berkovich, 1975; Butler, 1976; Bella et al., 2002).

Макроскопічна будова печінки у більшості курейнесучок віком 166 діб відповідала природній будові органа - пружної консистенції, темно-червоного кольору. У 30 \% курей віком 166 діб, 60 \% - 300 діб та у всіх досліджуваних курей віком 530 діб печінка була дещо збільшена, при цьому поверхня гладка і волога, консистенція в'яла, орган легко рветься. Краї печінки притуплені, капсула напружена, при розрізі паренхіма вибухає за межі капсули. Печінка всіх досліджуваних курей-несучок була нерівномірно забарвлена - 3 ділянками сіруватого, сіро-жовтого, глинистого кольору (особливо у старшої вікової групи). Варто також зазначити, що в курей віком 530 діб у жирових депо, особливо в ділянці живота, в міжм'язовій клітковині і навколо клоаки макроскопічно виявляли підвищений вміст жиру світло-жовтого кольору, що вказує на ознаки загального ожиріння птиці (рис. 1).

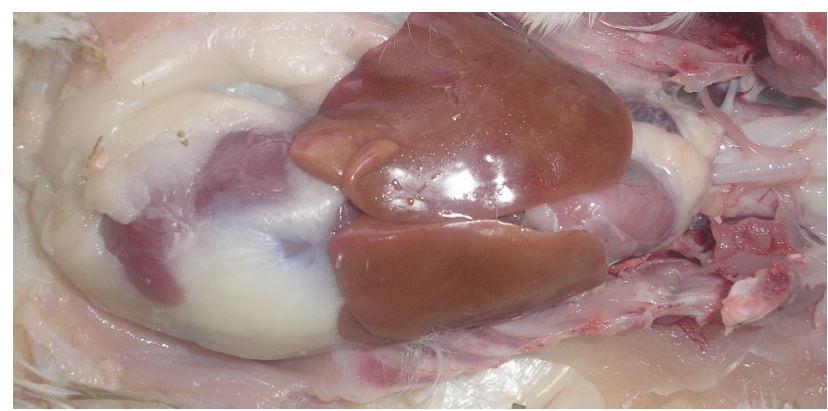

Рис. 1. Розтин курки-несучки віком 530 діб. Ознаки загального ожиріння птиці

За мікроскопічного дослідження печінки курейнесучок віком 166 діб встановлено, що часточкова будова органа переважно збережена (рис. 2, 3). Міжчасточкова сполучна тканина слабо розвинена, межі часточок визначали за тріадами. Паренхіма часточок складається 3 печінкових балок, які мають кільцеподібне розташування. Між печінковими балками проглядаються синусоїдальні гемокапіляри, в яких виявляли обмежену кількість еритроцитів та лімфоїдних клітин. Кожна балка утворена декількома полігональної форми гепатоцитами 3 заокругленими краями.
Межі гепатоцитів чіткі, ядра розташовані переважно по центру. Перисинусоїдні простори звужені та майже не простежуються. Ендотеліальні клітини плоскі, щільно прилягають до гепатоцитів. У частини досліджуваних курей цієї групи печінкові часточки розташовувались невпорядковано, внаслідок чого була порушена їх балочна структура. При цьому цитоплазма гепатоцитів дещо мутнувата, проглядається зернистість. Центральні та міжчасточкові вени помірно заповнені еритроцитами, дещо здавлені.

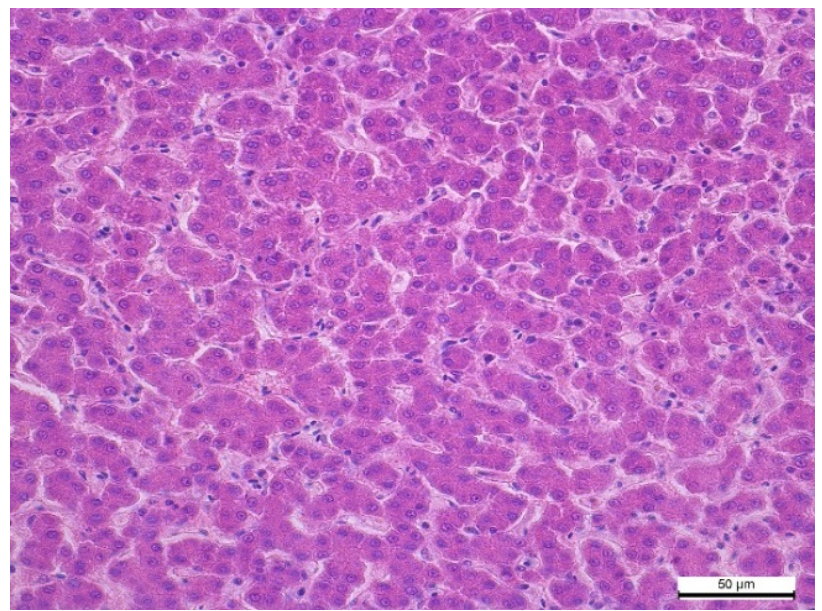

Рис. 2. Виражений чіткий рисунок балкової будови тканини печінки курей-несучок віком 166 діб. Гематоксилін та еозин. Ок. 10, об. 40

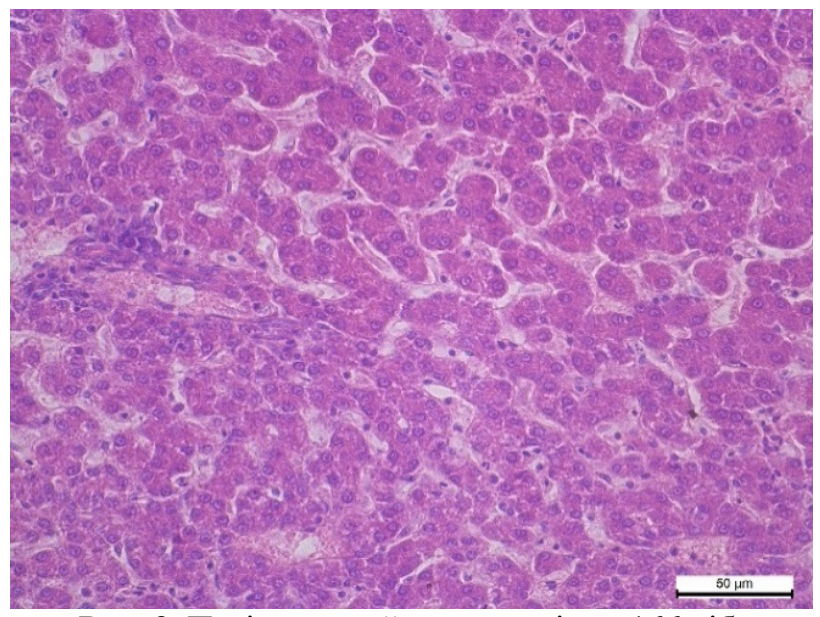

Рис. 3. Печінка курей-несучок віком 166 діб. Гематоксилін та еозин. Ок. 10, об. 40

За дослідження гістологічних препаратів печінки курей-несучок віком 300 діб нами виявлено осередки дискомплексації балкової будови (рис. 4). У таких ділянках значна кількість гепатоцитів збільшені в об'ємі, цитоплазма просвітлена, ядра розташовані по периферії. У цитоплазмі гепатоцитів наявні дрібні жирові вакуолі, що свідчить про розвиток дрібнокрапельної жирової дистрофії (рис. 5). Синусоїдальні гемокапіляри переповнені ядерними еритроцитами. 


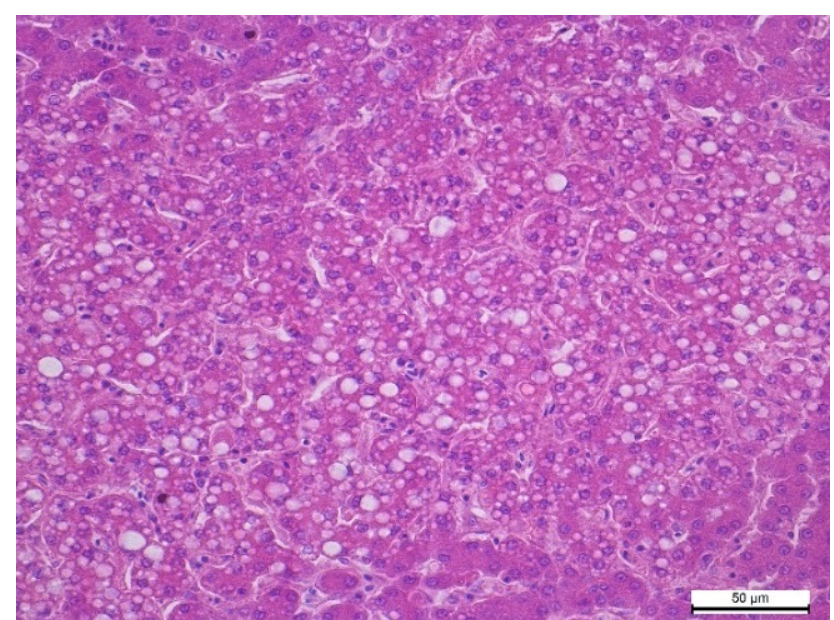

Рис. 4. Печінка курей-несучок віком 300 діб.

Осередки дискомплексації балкової будови.

Гематоксилін та еозин. Ок. 10, об. 40

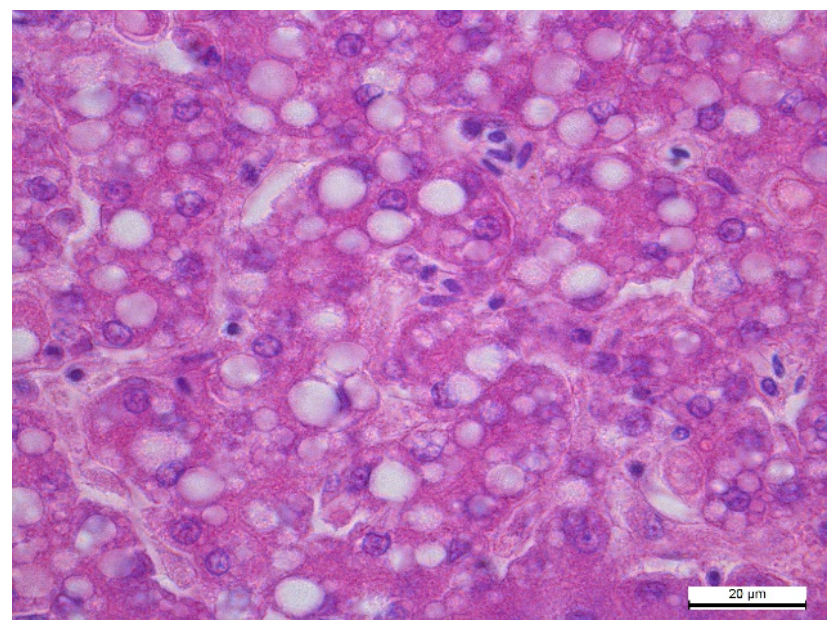

Рис. 5. Фрагмент рисунка 4. Жирові вакуолі у цитоплазмі гепатоцитів. Гематоксилін та еозин. Ок. 10 , об. 100

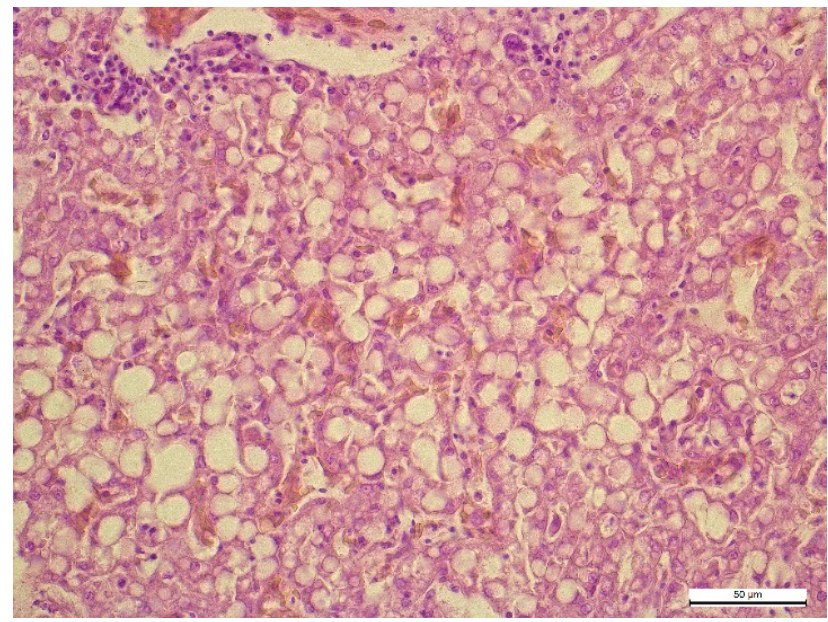

Рис. 6. Печінка курей-несучок віком 530 діб.

Наявність великих жирових вакуолей в гепатоцитах.

Гематоксилін та еозин. Ок. 10, об. 40

Печінка курей-несучок віком 530 діб переважно збільшена, набухла, жовтого кольору, була в'ялої консистенції, на розрізі часточкова структура не ви- ражена, на лезі ножа залишається сальний наліт. Мікроскопічним дослідженням гістологічних зрізів печінки курей даної групи виявлено виражену дистрофію органа, що проявлялося дифузною дискомплексацією балочної структури, збільшенням в об'ємі гепатоцитів, накопиченням в цитоплазмі останніх, різних за величиною, а переважно крупних жирових вакуолей (рис. 6). При цьому ядра відтіснені в одному з напрямків у бік полюсів клітини. Синусоїдальні гемокапіляри та центральні вени переповнені кров'ю. Біля центральних, міжчасточкових вен та вен печінкових тріад в печінці курей цієї вікової групи часто виявляли лімфоцитарні скупчення різного розміру.

\section{Висновки}

Підсумовуючи результати гістологічного дослідження печінки курей-несучок, можна стверджувати, що вже в 166 діб у 30 \% досліджуваної птиці починаються структурно-функціональні порушення органа. У курей-несучок віком 300 діб виявлено осередки дискомплексації балкової будови печінки, а в курей 530 діб - дифузне ураження всіх її частин. Встановлена наявність дрібнокрапельних та крупнокрапельних жирових вакуолей у гепатоцитах. Виявлені гістологічні зміни в печінці узгоджуються з результатами біохімічного аналізу сироватки крові досліджуваної птиці та свідчать про розвиток жирової дистрофії печінки.

Перспективи подальших досліджень. Результати проведеного нами комплексного дослідження можуть слугувати підгрунтям для пошуку й апробації нових гепатопротекторних препаратів та визначення їхнього впливу на різних етапах розвитку патології печінки.

\section{References}

Bancroft, J. D., Layton, C., \& Suvarna, S. K. (2013). Bancroft's Theory and Practice of Histological Techniques. 7th edition. Churchill Livingstone: Elsevier, 672. https://www.elsevier.com/books/bancrofts-theoryand-practice-of-histological-techniques-e-book/suvarna/ 978-0-7020-5032-9.

Bella, D. L., Hirschberger, L. L., Kwon, L. L. et al. (2002). Cysteine metabolism in periportal and perivenous hepatocytes: perivenous cells have greater capacity for glutathione production and taurine synthesis but not for cysteine catabolism. Amino Acids, 23, 453-458. doi: 10.1007/s00726-002-0213-z.

Bodrova, L. F. (2009). Gistologicheskie i gistohimicheskie osobennosti struktury pecheni kur, poluchavshih nizkokalorijnye kormosmesi i raciony s raznym urovnem obmennoj jenergii. Dostizhenija nauki i tehniki APK, 3, 51-53. https:/cyberleninka.ru/article/n/gistologicheskie-igistohimicheskie-osobennosti-struktury-pecheni-kurpoluchavshih-nizkokaloriynye-kormosmesi-i-ratsionys-raznym/viewer (in Russian). 
Butler, E. J. (1976). Fatty liver diseases in the domestic fowl. Avian Pathology, 5(1), 1-14. doi: 10.1080/03079457608418164.

Danilov, A. P., \& Berkovich, V. I. (1975). Vozrastnye osobennosti morfologii i gistohimii pecheni kur. Zemlja sib. dal'nevost. Omsk, 12, 9-10 (in Russian).

Dunets, V. Iu., \& Slivinska, L. H. (2017). Profilaktyka khvorob pechinky u kurei yaiechnoho napriamku produktyvnosti. Nauk. visnyk LNUVMBT imeni S. Z. Gzhytskoho, 19(73), 55-60. doi: 10.15421/nvlvet7312 (in Ukrainian).

Dunets, V. Iu., \& Slivinska, L. H. (2018). Klinichna syndromatyka kurei-nesuchok krosu "Loman-Braun" v umovakh hospodarstva. Nauk. visnyk LNUVMBT imeni S. Z. Gzhytskoho, 20(83), 341-346. doi: 10.15421/nvlvet8368 (in Ukrainian).

El-Katcha, M. I., Soltan, M. A., El-Naggar, K., ElShobokshy, S. A., \& El-Erian, M. A. (2019). Laying performance, fat digestibility and liver condition of laying hens supplemented with vitamin B12 or biotin and/ or bile acids in diet. Slov Vet Res, 56(22), 341352. doi: 10.26873/SVR-773-2019.

Erehina, G. N. (1990). Mikromorfologicheskie osobennosti stroenija pecheni kur. Sostojanie i razvitie morfologicheskih issledovanij domashnih i dikih ptic. Cheljabinsk, 41-43 (in Russian).

Hohlov, I. V. (2007). Morfogenez patologii pecheni u kur $\mathrm{v}$ vozrastnom aspekte. Avtoreferat dissertacii na soiskanie uchenoj stepeni kandidata veterinarnyh nauk. Ekaterinburg: UrGSHA, 3-5 (in Russian).

Horalskyi, L. P., Khomych, V. T., \& Kononskyi, O. I. (2005). Osnovy histolohichnoi tekhniky i morfofunktsionalni metody doslidzhen u normi ta pry patolohii. Zhytomyr: "Polissia" (in Ukrainian).

Kelberg, N. A., \& Sadovnikov, N. V. (2010). The role of the liver in the metabolism of birds. The morphological changes in the poultry liver while using anti homotoxic therapy. Agrarian Bulletin of the Urals, 1(67), 60-63.

Melnyk, A. Iu. (2015). Analiz i perspektyvy haluzi ptakhivnytstva Ukrainy, poshyrennia ta klasyfikatsiia metabolichnykh khvorob silskohospodarskoi ptytsi. Nauk. visnyk veterynarnoi medytsyny. Bila Tserkva, 2, 67-73. http://nbuv.gov.ua/UJRN/nvvm_2015_2_14 (in Ukrainian).

Nikitin, Ju. P., Kurilovich, A. I., \& Davyshhin, G. S. (1985). Pechen' i lipidnyj obmen. Novosibirsk: Nauka (in Russian).

Sarkisova, D. S., \& Perova, Ju. L. (1996). Mikroskopicheskaja tehntehnika: Rukovodstvo. M.: Medicyna (in Russian).

Vashchyk, Y., Shcherbyna, R., Parchenko, V., Bushueva, İ., Gutyj, B., Fotina, H., Fotina, T., \& Stronskyi, Y. (2020). Histological study of a corrective influence of a compound potassium 2-((4-amino-5(morpholinomethyl)- 4h-1,2,4-triazol-3-yl)thio) acetate (pkr-173) on the state of chicken's liver under infection by pseudomonas aeruginosa. Journal of Faculty of Pharmacy of Ankara University, 44(1), 117. doi: $10.33483 /$ jppau.567757.

Vrakin, V. F., \& Sidorova, M. V. (1999). Anatomija i gistologija domashnej pticy. M.: Kolos (in Russian). 